\title{
The Nuclear Uncanny in Oceania
}

Jessica Hurley

\section{(2) OpenEdition}

1 Journals

Electronic version

URL: https://journals.openedition.org/ces/396

DOI: $10.4000 /$ ces.396

ISSN: 2534-6695

\section{Publisher}

SEPC (Société d'études des pays du Commonwealth)

\section{Printed version}

Date of publication: 30 November 2018

Number of pages: 95-105

ISSN: 2270-0633

\section{Electronic reference}

Jessica Hurley, "The Nuclear Uncanny in Oceania", Commonwealth Essays and Studies [Online], 41.1 I

2018, Online since 05 November 2019, connection on 25 August 2021. URL: http://

journals.openedition.org/ces/396; DOI: https://doi.org/10.4000/ces.396

\section{(c) (i) () $\Theta$}

Commonwealth Essays and Studies is licensed under a Licence Creative Commons Attribution - Pas d'Utilisation Commerciale - Pas de Modification 4.0 International. 


\section{The Nuclear Uncanny in Oceania}

This article analyses the unsettling effects of the nuclear age in contemporary Oceania. Through a reading of James George's Ocean Roads (2006), a novel that incorporates nuclear legacies into the Māori kinship system of whakapapa, I show how Māori epistemologies become a vital resource for the Indigenous Pacific as it faces the long-term legacies of nuclear colonialism.

Literary criticism defines the nuclear uncanny as the experience of traumatic anxiety produced by the anticipation of a future nuclear apocalypse (Saint-Amour). In Oceania, however, the nuclear age manifests itself in a way that is very different from the anticipatory trauma that Paul Saint-Amour describes as the pre-August 1945 reality of Hiroshima and Nagasaki residents and the Cold War condition of city-dwellers living in what they know to be atomic targets (59-69). From the wartime atomic bombings of Hiroshima and Nagasaki, to the 315 nuclear weapons detonated by the United States, the United Kingdom, and France across Oceania between 1946 and 1996, to the infrastructures of the US nuclear-military-industrial complex that continue to structure Pacific Islander life in the present, the nuclear condition in Oceania has been one of nuclear violence in the present rather than in the future: of action rather than anticipation, of structure rather than dreaded event. ${ }^{1}$ In one of the most canonical poems to come out of Oceania's reckoning with its particular experience of nuclearization, Māori poet Hone Tuwhare's "No Ordinary Sun," Tuwhare locates the apocalyptic impact of the nuclear age not in a future atomic war but in the environments of the devastated present: "O tree," he writes, "in the shadowless mountains / the white plains and / the drab sea floor / your end at last is written" (17). Addressing the irradiated environments that index the Pacific experience as the West's nuclear laboratory and battleground, where the "monstrous sun" is both the sun and the weapon that seeks to mimic it, where the tree is both itself and its own ghost, Tuwhare's speaker is not experiencing a nuclear uncanny based on waiting for a missile that may or may not be on its way. Instead, the nuclear uncanny that appears in "No Ordinary Sun" is an experience of the forced defamiliarization of the everyday world by the colonial and neo-colonial nuclear infrastructures that produce unevenly distributed harm in the present. ${ }^{2}$

Echoing Tuwhare, anthropologist Joseph Masco offers a useful development of the nuclear uncanny in The Nuclear Borderlands (2006) by redefining it as the defamiliarizing experience of "inhabiting an environmental space threatened by military-industrial radiation" (28) in the present rather than of waiting for potential bombings in the future. For Masco, radiation is uncanny in that it ruptures two of the West's most profound epistemological premises about time and space: the linear, cause-and-effect logic of action in time, and the separability of the individual body from its environment in space.

1. For the history of nuclear bombings in the Pacific, see Maclellan. For the militarization of Oceania, see the essays collected in Camacho and Shigematsu (eds.). Tuwhare witnessed the devastated environment of Hiroshima firsthand in 1946 as a member of the New Zealand forces allocated to the occupying British Commonwealth Occupation Force.

2. For a survey of Pacific Islands literature that responds to nuclear bombings in the Pacific, see Keown (89-99). 
"One psychosocial effect of nuclear materials," Masco writes, "is to render everyday life strange, to shift how individuals experience a tactile relationship to their immediate environment. This gets at the root definition of the uncanny as Unheimliche [sic], or the unhomely, for the invisibility of radiation can make any space seem otherworldly, strange, and even dangerous. Indeed, what could be more 'unhomely' than the introduction of nuclear materials into one's everyday environment or body?" (33-4). Within Masco's research area in the United States, radiation becomes uncanny as it disrupts the linear temporalities and clear body-environment distinctions that make peoples raised with Western epistemological assumptions feel at home in the world. Yet, this then poses a further question about the nuclear uncanny in Oceania: what does the uncanny, which is based on epistemic rupture, look like within non-Western epistemologies?

Following Houston Wood's call for a "cultural studies for Oceania" that moves beyond incorporating Native Pacific experiences into Western theoretical frameworks, this article seeks to analyse a specifically Indigenous, Oceanic form of the nuclear uncanny - one that emerges within, rather than attempting to smooth over, "the manifold incompatibilities that exist between Euro-American and Native Pacific Islander epistemologies" (340). An approach to the nuclear uncanny in Indigenous Oceania must begin by acknowledging that the uncanny itself emerges from a specific Western relationship to Indigenous epistemologies, peoples, and histories. Freud's 1919 essay "The Uncanny" defines the uncanny experience as a colonial one: "An uncanny experience," he writes, "occurs either when repressed infantile complexes have been revived by some impression, or when the primitive beliefs we have surmounted seem once more to be confirmed" (226). For Freud, the characteristics that define the uncanny animism and magical thinking about cause and effect - are the return of an Indigenous repressed, as Freud writes into time ("we in the West have evolved from the 'primitive" beliefs of our forefathers") the colonial operations that are actually happening in space ("we in the West are currently involved in colonial and settler-colonial operations aiming to wipe out Indigenous epistemologies wherever we find them”). Thus, as Renée Bergland has argued, "the uncanny is the unsettled, the not-yet-colonized, the unsuccessfully colonized, or the decolonized" (11); in the context of colonialism, the uncanny is the encounter with an Indigenous epistemology - informed specifically by Freud's reading about Aboriginals in the Pacific (McCann 43) - that the colonial West has failed to eradicate. ${ }^{3}$

Freud's uncanny predates the arrival of the nuclear age by several decades. Yet the relationship between uncanniness and indigeneity is not lost in the transition from the aesthetic uncanny that Freud analyses in his essay to the nuclear uncanny that marks its more contemporary iteration. The unsettling qualities that Masco describes as central to the nuclear uncanny - the uncanny agency of nuclear materials and their non-linear temporalities - bear a striking resemblance to the animism and the troubling re-emer-

3. Building on Gayatri Chakravorty Spivak's concept of "worlding," Avril Bell argues that all settler-colonial projects are designed to transform the unheimlich into the heimlich: "The new and alien world had to be made homely by the transplantation of plants and animals [...] as well as an entire social world of political, economic, legal and social institutions and practices" (14). Bell's analysis of the difference between the theory of the uncanny that emerges from within postcolonial studies, which figures the uncanniness of the Native as the return of the past repressed, and that which is important to contemporary Indigenous philosophy and politics, which insists that the Native has always been coeval with but "unencompassable within the worldview of western modernity" (114, author's emphasis), is important; this article is operating within the latter model. 
gence of that which should have disappeared which Freud locates at the heart of the uncanny experience, and which he marks as Indigenous. Indeed, the West's emergence into the nuclear age has been defined since its beginning by a turn to the supernatural that indicates the extent to which nuclear physics and technologies have challenged the epistemologies of Western rationalism; think of Oppenheimer's interpellation of himself as Krishna, an avatar of Vishnu, at the moment of the first nuclear detonation ("I am become death, destroyer of worlds"), or of the Christian mysteries invoked by the naming of the site at which that test would take place (Trinity), or of the profound ways in which nuclear physicists were challenged by their encounters with quantum physics throughout the twentieth century (Einstein's descriptions of "spooky action at a distance" and "voodoo forces," for example). ${ }^{4}$

Nuclear materials are, moreover, more aligned with Indigenous epistemologies than they are with the cosmology of Western science. They are agential in a way that fits more neatly into an animist worldview than an anthropocentric one, and their unpredictable temporalities are closer to those of Indigenous spiral time than they are to EuroAmerican linear time. ${ }^{5}$ The compulsion to name nuclear laboratories and technologies after Native American nations, practices, and spaces that Masco notes at Los Alamos (119-22) marks the irruption of supposedly repressed Indigenous epistemologies into the heart of colonial science. Every research "kiva" and Blackfoot, Navajo, or Zuni test detonation in the Pacific is a symptom of the profound yet disavowed affiliation between nuclear and Native epistemologies even as the bulk of nuclear violence is visited upon Native peoples. In events like Operation Redwing (1956), the West sublimates its own discomfort with the overlap between nuclear and Native epistemologies by naming bombs after Native nations in the Americas and then using them to obliterate contemporary Native Pacific Islander spaces at Enewetak and Bikini atolls, in tests designed to move the nuclear from the realm of the Indigenous uncanny into the realm of Western data. ${ }^{6}$ Freud, one has to think, would be impressed by the extent to which incomplete repressions of the Indigenous uncanny have structured nuclear science from the very beginning of the nuclear age.

Like any uncanny object, then, the nuclear is uncanny not because of its novelty but because it marks the continued existence of that which has been incompletely repressed, suppressed, or oppressed: indigeneity. And while the Freudian uncanny functions as "a repository for what, in European enlightenment discourses, was placed outside the episteme and constructed as 'pre-' or 'non-' scientific in order to dismiss the existence of different epistemological claims" (Emberley 26), the nuclear uncanny flips the hierarchy of knowledge upon which the uncanny itself is based: while the uncanny places Indigenous epistemologies outside of the boundaries of what constitutes knowledge as such, nuclear science - supposedly the ultimate achievement of Western rationalism - finds itself likewise positioned outside of Enlightenment norms and assumptions, alongside the repressed forms of Native knowledge with which it more closely aligns. We might

4. Keller shows how nuclear and quantum physics trouble the most foundational epistemological certainties of Western science, and describes the consequent "crisis of faith" among physicists that would define the field for half a century.

5. For more on the temporal affiliations between Native and nuclear epistemologies, see Hurley (774-80).

6. While not addressing indigeneity, Russell Meeuf has analyzed film noir's abusive detectives as an exemplar of the inherent violence of the "attempt to 'know' what's coming next and make sense of a chaotic world" that the US, at minimum, performs in the face of the nuclear uncanny (285). 
think here of the coat of arms designed by Ernest Rutherford, the Aotearoa New Zealand physicist who first split the atom, upon his elevation to the peerage: a Renaissance alchemist and a Māori warrior are positioned symmetrically on either side of the crest, two figures of the occult and Indigenous knowledges against which Enlightened rationalism has defined itself transformed into metonyms for the mysteries of nuclear science. In Rutherford's crest as elsewhere, the nuclear uncanny is always already the Indigenous uncanny.

This realignment of Indigenous epistemologies as affiliated with, rather than opposed to, the nuclear age is central to one of the most unusual nuclear texts to emerge from Oceania in the twenty-first century, Māori author James George's 2006 novel Ocean Roads. Where Tuwhare represents the nuclear uncanny mimetically, by representing the defamiliarizing of the everyday world through nuclear violence, George's novel takes a more interventionist approach by redefining the nuclear uncanny itself from a Māori perspective. Ocean Roads is an intergenerational family saga within which characters from key points in nuclear history are incorporated into the family of a Māori woman, Etta Henare. While the story is told in a non-linear fashion, through interleaved episodes narrated in the present tense, the chronological accretion of Etta's kinship relations begins when she meets and has a love affair with Joaquin Alvarez, an American soldier stationed in Aotearoa New Zealand. Originally from New Mexico (a territory marked as specifically nuclear), Joaquin goes on to die in the taking of Tinian, the island from which the planes that bombed Hiroshima and Nagasaki would be launched. Etta has a son by Joaquin named Troy; after the war, she meets and marries Isaac, a British nuclear physicist who worked on the Manhattan Project at Los Alamos and visited Nagasaki shortly after the bombing, and has a second son, Caleb. Troy grows up to become an army sniper in the "hot" Cold Wars in Malaya and Vietnam while Caleb becomes a math student and anti-war activist; they both have a sexual relationship with Akiko, a Japanese dancer and hibakusha who was born in Nagasaki on the day of the bombing, and one of the brothers is the father of Akiko's daughter Rai. Caleb develops leukaemia, strongly suggested to be related to his father's exposure to nuclear materials during and after the war; after being treated with radiotherapy, he commits suicide during an antiVietnam War protest at which Troy, attempting to save his brother while also undergoing a PTSD flashback, also dies.

The novel thus brings together nuclear histories (the Manhattan Project, the bombing of Nagasaki, the intergenerational cancers resulting from radiation exposure, the medical use of radiation) and nuclear geographies (New Mexico, Tinian, Nagasaki, the Antarctic, Aotearoa New Zealand) into a single Māori social form: the whānau, or extended (and not necessarily biological) family. Critical commentary on the novel has described this formal conceit in Western terms, in which the heimlich (or homely) family is ruptured or rendered unbeimlich (uncanny, unhomely) through its encounter with nuclear histories. Elizabeth DeLoughrey, for instance, argues that the three younger characters (Troy, Caleb, and Akiko) are "carrying the metaphysical and corporeal legacies of militarized radiation" (480) and that Caleb's leukaemia signifies "a rupture in the family ecology arising from the legacy of militarized radiation" (481). Such a reading would align Ocean Roads with "No Ordinary Sun," representing the nuclear uncanny as something that enters the beimlich space of the family and blows it apart. Yet, the novel itself stages two different responses to the uncanny unknowability of the 
nuclear, suggesting a more complex intersection of the nuclear uncanny with specifically Māori conceptions of family and kinship.

The nuclear uncanny appears in several aspects of the novel. Caleb's leukaemia is dislocated in time and space from Isaac's exposure to radiation in New Mexico and Japan, while Akiko, herself exposed to radiation at Nagasaki, lives her life with unknowable levels of damage that may or may not kill her in the end. The nuclear age is marked, here as elsewhere, by an encounter with the radically unknown, a world outside of Western science that seems to challenge the functionality of that science itself. In narrating the response of Western science to that challenge, however, George underscores its continuities with colonial violence against racialized and Indigenous bodies and spaces. When Akiko describes her childhood to Caleb, for example, it is as a ritualized encounter with scientific whiteness: "Every two years,' she says, 'the week of my birthday, I had to go for medical tests. I had to take all my clothes off and get into a white robe... They tested my heart rate, the oxygenation of my blood, made me exercise in a room with white walls to match my white robe. The white of my bones in the X-rays. They did everything but treat me. Treat us"' (52). The West responds to the unknown consequences of its own nuclear violence with a repetition compulsion straight out of Freud, an act of repeated scientific violence whose goal is not to beal but to know.

Similarly, when Isaac visits Nagasaki shortly after the end of World War II as part of a mission to transform the unknown consequences of the nuclear bombing into scientific data, the mission is described in language that underscores the continuation of militarized violence in the supposedly peacetime scientific excursion: "A month after the war ended, the Manhattan Project Atomic Bomb Investigation Group flew into Japan in a converted B-29 bomber, much as the bombs themselves had" (249). In the age of scientific militarism, George suggests, the scientific urge to know what the bomb did is as violent an act as the scientific urge to know which led to its creation, the scientists rendered equivalent here to the bombs that they dreamed up and produced. Both Western science and Western colonialism respond to the uncanny, whether the nuclear or the Indigenous uncanny, by trying to transform the unknown into the known, the unheimlich into the beimlich. George underscores the violence that subtends such desires in the settler-colonial setting that seeks to transform unbeimlich Indigenous lands into the home-space of colonists through practices of extermination and forced assimilation. He also highlights the continuation of such eliminationist violence in the nuclear setting that, under Western rule, turns Indigenous people and hibakusha into lab rats, as when Merril Eisenbud, the head of the US Atomic Energy Commission, says in 1956 that Native Uterik Islanders should be experimented on after nuclear tests because they are "more like us than mice" (Johnston 25).

Within the novel, the Euro-American response to the nuclear uncanny results in a temporal stuckness, a flattening of historical time into a permanent present with no past or future. When Isaac arrives in Nagasaki, the urban environment that had accreted over hundreds of years of human history has been wiped away: "the map more resembled a city than the city did. There was a desert sense to it. Centuries of human works had been swept up and sucked back into sand" (249). Describing the results of the bombing to Caleb from within the mental asylum in which Isaac himself has been stuck for years, Isaac again evokes the permanent present of the nuclear uncanny: "How 
many died?' asks Caleb. 'I don't know,' says Isaac. 'But we shouldn't use the past tense. With the effects of radiation, they'll still be dying"' (252). When Caleb is diagnosed with the leukaemia that is his own manifestation of the nuclear uncanny, the language used by the doctor to explain the disease represents his cancer as a kind of bone-deep stuttering stuckness: "When they are mature enough to leave the bone marrow, the white blood cells are released into the bloodstream to circulate around the body. Acute lymphoblastic leukaemia is when there are too many immature lymphocytes, lymphoblasts, sometimes called blast cells. They fill up the bone marrow, prevent it making the replacement mature cells that the blood and the body needs" (268). The treatment for Caleb's cancer is also an instance of uncanny repetition or stuckness: radiotherapy, piling radioactive exposure onto radioactive exposure and calling this repetition progress. No wonder that Caleb, too, becomes stuck in the repetitive temporalities of Western nuclear science; when Akiko opens his notebook expecting to find the usual equations and drawings, she finds instead "a single word written over and over. Radiation" (277, author's emphasis).

George thus stages the Euro-American response to the nuclear uncanny as a violent attempt, continuous with older forms of colonial violence, to transform the unknown into the known that can do nothing but perpetuate more acts of violence and foreclose the possibility of radical change (critiquing British detonations in the nuclear-colonial Pacific, Isaac connects nuclear science to perpetual war: "another testing program, for another war that had been searched for and sighted just over the horizon, like a landfall [255]). However, Ocean Roads also offers an alternative vision of what it might look like to encounter the nuclear uncanny from within a specifically Māori cosmology. In a suggestive turn of phrase, Anthony Carrigan describes how the novel "domesticates" (265) transnational histories of violence and processes of recovery into the form of the family saga. Chris Prentice goes a step further to define the form of this family within Māori kinship systems, arguing that “indications of the novel's Māori concerns invoke place in ways that link geography with whakapapa, the generative and iterative network of interrelations that constitute genealogical, historical and spiritual subjectivities" (1006). Whakapapa is a Māori model of kinship that positions the individual within an inclusive web of relations across time and space. Importantly, as Avril Bell describes it, whakapapa differs from Western logics of descent that focus on the purity of the "bloodline" because it "works according to an opposite, inclusive rather than divisive, logic. It is used continually in everyday life in Māori society as people work to establish relationships and points of connection with others they meet, searching for a common ancestor or close points of connection. Thus, if you share one ancestor, no matter how many generations ago, your whakapapa connects you" (62-3). Whakapapa is therefore able to incorporate non-biologically related characters such as Isaac and Akiko into Etta's kinship group, integrating Los Alamos and Nagasaki into Māori space. The "domestication" of nuclear events and spaces within the novel's form, then, is more than a plot device for conceiving of planetary-scale events on the scale of the family or a way to show how nuclear legacies tear families in Oceania apart (as Prentice, Carrigan, and DeLoughrey argue); rather, it is an incorporation of the nuclear uncanny into the Māori system of whakapapa, a making-Māori of the nuclear age.

Nuclear whakapapa is a theme that runs throughout the novel. When Troy visits the Trinity site, for example, he experiences it through the lens of kinship relations between 
human and non-human nuclear objects: "The only things he knows about his father is that he was born in the deserts of New Mexico and died on a Pacific atoll. An atoll where they built the airfield that launched the B-29s that dropped the atomic bombs on Japan to end World War Two. His father's blood was in that coral runway. And that bomb was in his stepfather's blood" (121). A section of the novel told from a more external narrative perspective similarly interleaves the story of Etta's expanding kinship network with the mid-century developments of nuclear history:

One morning Isaac sits at the table on the grass outside their bach, reading a newspaper [...]. The first sentence stills him, the second closes his eyes. The Soviet Union has exploded its first atomic bomb. He stands, drops the paper on the table and bashes the edge of his hand against the bach's wall.

Nineteen-fifty offers an apex in the century. More armies gather, more letters and phone calls and ultimatums are sent to open dialogue and close borders.

Away from it all a man and a woman pitch a tent by a fence, then disassemble an old bach and build something larger, something they hope will be more permanent, set against the safety of the hillside. A pole house, its back to the hillside, its face to the sea wind. The three then become a four when another boy is born. They name him Caleb. (176-7)

Later, Isaac describes his own role in developing the atom bomb in equally paternal terms: by the time he became morally horrified by his own actions, he tells Caleb, "I'd already spoonfed the monster, fed and clothed it and pushed it out in a little red wagon, out into the world" (342). Operating under the sign of whakapapa, the nuclear becomes contiguous with the whānau, a part of the cosmological and kinship relations that define the world of the novel. The nuclear is still horrifying here, but rather than rupturing the family ecology, as DeLoughrey concludes, the nuclear uncanny as monstrous child is able to be incorporated into the heimlich home space of whakapapa.

Whakapapa also structures Ocean Roads on a larger scale, becoming something like a principle of literary form (indeed, since whakapapa is both the genealogy and the act of reciting the genealogy, Ocean Roads could be defined as a novelization of whakapapa itself). Susan Najita writes that "Māori notions of genealogy presuppose an intimate connection with the past $[\ldots]$. The term whakapapa literally means 'to lay one thing upon another' or to lay one generation upon another (Barlow 173). The past coexists with the embodied present, constituting a person's location and being" (100). From this perspective, George's use of the present tense across different periods of time starts to make a different kind of sense. While the novel is profoundly historical, weaving together a militarized history of the twentieth century, its model of history is distinctly non-linear; not only are the events narrated out of chronological order, they are also all narrated in the present tense. Across the novel as a whole, therefore, each of the historical events being described comes to "coexist with the embodied present" of the text itself. Compared to the rigidly linear temporalities of Western science that produce the experience of the nuclear uncanny for Masco, the co-existence of different times in the lived present makes a beimlich kind of sense within the multitemporal 'home' that whakapapa composes. When Akiko learns of Caleb's cancer, she has no difficulty in conceptualizing the experience within a larger set of kinship relations across time and space: “'You think I don't recognise you?' she says. 'You think I haven't seen you before? Hundreds of you, stumbling to death?"' (328). As kin to the hibakusha of Nagasaki, Caleb's experience is laid upon theirs like a transparency or palimpsest; their past is his present, their experience his own. 
Akiko's conflation of Caleb with the hibakusha through the doubly-inflected pronoun "you" also indicates the second formal aspect of whakapapa in the novel: the "kinship I." As Marshall Sahlins explains it, "the Maori pronoun 'I' is also used to refer to one's entire kinship group (hapuи, usually), past or present, collectively or in regard to famous members" (21). Sahlins notes how, using the kinship I, Māori speak of the actions of members of their whakapapa using the first-person pronoun: my ancestor's actions are my actions; what happened to them has happened (is happening) to me; their promises are my promises and their responsibilities are my responsibilities. In Ocean Roads, we see the kinship I at work when, for example, Etta (a famous photographer) is hired to photograph the Trinity site for a news magazine; while Isaac is the atomic physicist with the connection to Los Alamos, due to their connection through whakapapa, "she knows they asked her to do the shoot at the Trinity site not just because of her reputation as a photographer, but because of her personal history. Her stake in that ground" (143). And since "for Maori, kinship is cosmological inasmuch as all things - including plants, animals, and 'the very elements' - descend from the same Sky Father (Rangi) and Earth Mother (Papa)" (Sahlins 30), the kinship I can include not only the hibakusha that are a part of Caleb's whakapapa or the shared responsibility of Etta and Isaac, but also the atom bomb that injured them, the uranium that produced it, the ground at Trinity in which both Etta and Isaac have "stakes." In the same way that whakapapa allows for a beimlich experience of the non-linear temporalities that makes the nuclear seem unbeimlich in a Western cosmology, then, it also takes as heimlich the porosity of the self and the agency of non-human materials that is a key aspect of the nuclear uncanny.

To understand the nuclear uncanny as part of a whakapapa model of genealogy is to radically reframe the experience of the nuclear age in Oceania through a Māori lens. In Ocean Roads, such a reframing produces potentially different outcomes for individuals and communities than does understanding the nuclear age solely through a Western cosmology. In contrast to the Western experience of both the nuclear and the Indigenous uncanny, which seeks to render the unheimlich knowable through acts of violence, Māori whakapapa incorporates the unbeimlich into the heimlich through acts of responsibility and care. At the end of the novel, the violent stuckness that George presents as the Western nuclear condition is released into two different forms of loving movement. In the penultimate episode, Etta and Isaac, reconciled after a long estrangement, finally ride Isaac's motorcycle north to Te Rerenga Wairua, the leaping-place of the spirits, where human roads end and the ocean roads of Māori spirits begin. Their narrative is suspended at the moment where the end of the book coincides with the entrance into the spirit ways, with "the pages of the immense book of ocean waves leafing down onto the sand" (383), with relations of care re-established between Etta and Isaac and the human and spirit worlds re-joined.

In the novel's final episode, Akiko, too, manages to transfigure what had been an experience of loss and harm into an experience of care. Recalling the kinship I's porous selfhood, "in her mind her mother's face appears. A face built cell by cell every day Akiko has woken to the dawn" (382). Under the aegis of whakapapa, Akiko's nuclear injuries are experienced and understood differently: "Today I had another pain, this time in my heart. Maybe that's where they were all along. I asked it what it wanted to be, but it didn't answer. Today I realised you never left me. That you were the pains I felt. My reminder" (382, author's 
emphasis). Just as the novel itself tells stories of nuclear violence in the present tense such that its victims are never lost, are always with us, so Akiko realizes that the injuries that she shared with her parents also tie her into a web of relations that keeps them with her in the present. In the novel's final lines, Akiko's experience of whakapapa is what allows her to live with her traumatic nuclear experience creatively and honestly, hiding nothing: "Akiko stands from her work table, watching the vinyl disc circle. She waits a few bars then begins to dance [...]. She stops and takes off her clothes until she is naked. Lets her scars feel the air, the scars she has carried since the day she was born. Scars she has hidden from almost everyone. Baring them to the music" (383). No longer uncanny, hidden, unheimlich, the nuclear is now what can be lived with, shared, and collectively faced.

George's use of whakapapa as a literary form for nuclear storytelling thus exemplifies how, for Māori as well as other Indigenous peoples, "storytelling becomes a technique of 'resistance,' but resistance defined as a mode of incorporation, a way of taking in the violence of colonization as a vital part of the Indigenous experience and working through its material, spiritual, and representational effects" (Emberley 290). As Emberley argues, "by this process of incorporation-as-resistance the meaning of history is reconfigured as a process and not a fixed event in which effects, and futures, cannot be altered" (290-1). Ocean Roads certainly does this, incorporating the supposedly unassimilable nuclear uncanny into a Māori recitation of whakapapa in order to create different interpretations of the past and future of the nuclear Pacific. Yet the use of an incorporative model based specifically on kinship also suggests a more extensive intervention into the colonial realities of the nuclear age in contemporary Oceania.

Considering contemporary Indigenous sovereignty movements across the globe, Jeffrey Sissons argues that kinship cosmologies provide an alternate mode of political, social, and cultural organization that is the basis for Indigenous resistance to colonialism (33). In the nuclear context, reframing the nuclear through the lens of Mãori kinship cosmologies makes a specific kind of claim about the political possibilities of relating to the nuclear age. In Aotearoa New Zealand, as elsewhere, the sovereign power to make decisions about nuclear matters is reserved to the state - in this case, a settlercolonial state caught up in a fraught legal and historical struggle over the nature and scale of Māori sovereignty. ${ }^{7}$ The assertion that Māori are able to relate to the nuclear age through their own sovereign kinship practices, practices that provide a model for social organization that stand fully outside of the settler-colonial nation state, is thus a profound claim for Indigenous self-determination in the nuclear age. Indeed, decolonized sovereignty in Oceania has long been bound up with the capacity to have a decolonized, sovereign relationship to the nuclear (such as having the power to make decisions about exposure, remediation, reparation, and so on), as suggested by the region's major pan-Pacific Indigenous political organization, the Nuclear Free and Independent Pacific Movement. By writing nuclear history into the recitation of Māori whakapapa, then, George claims a decolonized relationship to the nuclear for Māori within a broader context of anticolonial struggle in Oceania. Eschewing the idea that the nuclear can only be reckoned with in relation to the colonial state, George models a sovereign

7. For a full history and analysis of Māori sovereignty claims stemming from the Treaty of Waitangi, and especially their intensification since the establishment of the Waitangi Tribunal in 1975, see Sorrenson (217-72). 
relation to nuclear materials in which Māori are at the centre, not the periphery, of the nuclear age.

In his 2001 poem "Whakapapa," Apirana Taylor invokes the relationality that is described in and created through whakapapa: "this is your inheritance / the sky and earth and all that lies between." In the nuclear age, the sky and the earth and all that lies between them are no longer a pastoral inheritance, as Taylor, with his descriptions of dole queues and drinking problems, well knows. Yet to inherit an irradiated world is still to have a sovereign place within it, a heimlich place that disrupts the political workings of the nuclear as well as the colonial uncanny. Nuclear colonialism has threatened to estrange Indigenous Oceanic peoples from their lands in perpetuity, inscribing the (neo) colonial violence of the nuclear age onto water and rock, body and bird and fish. And yet, as Ocean Roads shows, even the most colonial of weapons can be incorporated into a Māori worldview, a sovereign mode of relation that insists on the continuing presence of Indigenous peoples and their capacity to determine their own relationship to nuclear things. In this rewriting of the nuclear uncanny for Oceania, what haunts the West becomes kin for Māori: a monstrous child, perhaps, but one with which the people will reckon in their own way, on their own terms, between the earth and sky.

Jessica Hurley

University of Chicago

\section{Works Cited}

BARLow, Cleve. Tikanga Whakaaro: Key Concepts in Māori Culture. Auckland: Oxford UP, 1998.

BeLL, Avril. Relating Indigenous and Settler Identities: Beyond Domination. New York: Palgrave Macmillan, 2014.

BergLand, Renée L. The National Uncanny: Indian Ghosts and American Subjects. Hanover, N.H.: UP of New England, 2000.

Carrigan, Anthony. "Postcolonial Disaster, Pacific Nuclearization, and Disabling Environments." Journal of Literary \& Cultural Disability Studies 4.3 (2010): 255-72.

DeLoughrey, Elizabeth M. "Radiation Ecologies and the Wars of Light." Modern Fiction Studies 55.3 (2009): 468-98.

Emberley, Julia. The Testimonial Uncanny: Indigenous Storytelling, Knowledge, and Reparative Practices. Albany: State U of New York P, 2014.

Freud, Sigmund. "The Uncanny." 1919. Writings on Art and Literature. Ed. Neil Hertz. Stanford: Stanford UP, 1997. 193-233.

George, James. Ocean Roads. Wellington: Huia, 2006.

Hurley, Jessica. "Impossible Futures: Fictions of Risk in the Longue Durée." American Literature 89.4 (2017): 761-90.

JohnSTON, Barbara Rose. “More like Us than Mice': Radiation Experiments with Indigenous Peoples." Half-Lives and Half-Truths: Confronting the Radioactive Legacies of the Cold War. Ed. Barbara Rose Johnston. Santa Fe, N.M.: School for Advanced Research P, 2007. 25-54.

Keller, Catherine. Cloud of the Impossible: Negative Theology and Planetary Entanglement. New York: Columbia UP, 2015.

Keown, Michelle. Pacific Islands Writing: The Postcolonial Literatures of Aotearoa/New Zealand and Oceania. Oxford: Oxford UP, 2009.

Maclellan, Nic. "The Nuclear Age in the Pacific Islands." Contemporary Pacific 17.2 (2005): 363-72.

Masco, Joseph. The Nuclear Borderlands: The Manhattan Project in Post-Cold War New Mexico. Princeton, N.J.: Princeton UP, 2006.

McCann, Andrew. "Unknown Australia: Rosa Praed's Vanished Race." Australian Literary Studies 22.1 (2005): 37-50.

MeEuf, Russell. "Nuclear Epistemology: Apocalypticism, Knowledge, and the 'Nuclear Uncanny' in Kiss Me Deadly." LIT 23.3 (2012): 283-304. 
NajITA, Susan Y. Decolonizing Cultures in the Pacific: Reading History and Trauma in Contemporary Fiction. New York: Taylor \& Francis, 2008.

PrentiCE, Chris. "'Fractured Light': From Globalization's Hyper-Illumination to Culture as Symbolic Exchange.” Interventions 19.7 (2017): 996-1010.

SaHLins, Marshall. What Kinship Is - and Is Not. Chicago, IL: U of Chicago P, 2014.

SAINT-Amour, Paul K. "Bombing and the Symptom: Traumatic Earliness and the Nuclear Uncanny." Diacritics 30.4 (2000): 59-82.

Shigematsu, Setsu, and Keith L. Camacho, eds. Militarized Currents: Toward a Decolonized Future in Asia and the Pacific. Minneapolis: U of Minnesota P, 2010.

Sissons, Jeffrey. First Peoples: Indigenous Cultures and Their Futures. London: Reaktion Books, 2005.

Sorrenson, M. P. K. Ko Te Whenua Te Utu = Land Is the Price: Essays on Mãori History, Land and Politics. Auckland: Auckland UP, 2014.

Tuwhare, Hone. "No Ordinary Sun." Te Ao Hou, September 1959.

TaYlor, Apirana. Whakapapa: Poems. 2001. <https://www.wpm2011.org/node/442>. Consulted 24 April 2018.

WooD, Houston. "Cultural Studies for Oceania.” Contemporary Pacific 15.2 (2003): 340-74. 